\title{
RENAL AUTOEXPLANTATION AND PROTECTION AGAINST RENOPRIVAL HYPERTENSIVE CARDIOVASCULAR DISEASE AND HEMOLYSIS *
}

\author{
By E. E. MUIRHEAD, J. A. STIRMAN and F. JONES \\ (From the Departments of Pathology and Surgery, The University of Texas Southwestern \\ Medical School, Dallas, Texas)
}

(Submitted for publication June 15, 1959; accepted July 24, 1959)

Bilateral nephrectomy of the dog is associated with the development of hypertension (1), cardiovascular injury (2), and a hemolytic state (3). The cardiovascular injury is characterized by cardiac necrosis, followed in time by fibrosis; and arteriolar necrosis, followed by arteriolarsclerosis (4). The hemolytic state may be identified by a shortening of the survival of the erythrocytes in vivo (5). The hypertension of bilateral nephrectomy has been shown to be aggravated by sodium (6), sodium and dietary protein (7), and sodium plus alanine, lactate or pyruvate (8). The evaluation of this type of hypertension, as observed in the dog, has been standardized in our laboratory by giving the animal a prescribed amount of protein by diet and of sodium by vein (7).

In the currently reported experiments groups of nephrectomized dogs, receiving a prescribed amount of protein and sodium, were subjected to measurement of the arterial pressure and of the survival of the erythrocytes. After sacrifice, tissue from the viscera was prepared and the wall/ lumen ratio of the arterioles was measured as an index of the state of the arteriolar wall. Certain of these groups had the renal oblation after explantation of renal tissue either to the peritoneum or lungs. The experiments were designed to test for the existence of antihypertensive and antihemolytic functions of renal tissue which were devoid of excretory function.

\section{METHODS}

\section{Explantation procedures}

Group I: Whole kidney explanted to peritoneum. In 8 dogs the whole kidney was explanted to the peritoneum under sodium pentobarbital anesthesia as follows. 1) The left kidney was removed through an anterior midline abdominal incision. 2) The renal capsule was stripped and

* Supported by a grant from the National Heart Institute, Bethesda, Md. with a large single-edged razor blade, using a wooden block for a platform, the kidney was cut into serial cross sections about 3 to $4 \mathrm{~mm}$ in thickness, and the larger blood vessels at the hilum on each side of the papilla were cut away. 3) The segments of the kidney were placed in Gey's solution (15 to $20 \mathrm{ml}$ ) in a small Waring blendor, and the blendor was operated for $30 \mathrm{sec}-$ onds. 4) The remains from the blendor were pressed through a siliconized sieve ( 32 meshes per inch) into a beaker, with the aid of the closed end of a siliconized test tube. Small volumes of Gey's solution were added through the sieve to assist in this procedure. 5) The suspended bits of tissue (about $1 \mathrm{~mm}$ or less in size) were centrifuged in plastic tubes $(2,000 \mathrm{rpm})$ and washed once in abundant Gey's solution by agitating them back into suspension, then recentrifuging. 6) The final suspension was made to $100 \mathrm{ml}$ in a beaker, and to this suspension an antibiotic mixture was added so as to contain in the final $100 \mathrm{ml}$ volume the following : polymyxin B sulfate, 100,000 units (10 mg equivalent); neomycin sulfate, $100 \mathrm{mg}$ ( $70 \mathrm{mg}$ neomycin base equivalent); and bacitracin, 10,000 units. 7) The final suspension was injected into the peritoneal cavity through an indwelling polyethylene tube. The entire procedure, from clamping of the renal pedicle to the injection, required about 15 minutes. Sterile operating room precautions were used throughout.

Twelve to 33 days later (average 26 days), the opposite or right kidney was removed through a posterior incision, care being taken not to invade the peritoneal cavity. In the interval between the nephrectomies the animals were fed a mixture of commercially obtained dog biscuits and canned food for dogs.

Group II: Explantation of medulla to lungs. In 8 dogs the explantation procedure was conducted under open drop ether anesthesia. The left kidney was removed; the capsule was stripped and the kidney was cut into serial cross sections as before. Next, with each cross section on its side, the fibrovascular segments on each side of the papilla were removed; with a single-edged razor blade the cortex was separated from the medulla precisely at the vascular arcade. The cortex was discarded and the medulla, from the vascular arcade to the papillary tip, was placed in the Waring blendor, and from then on treated in the same manner as the whole kidney with the exception that antibiotics were not added. The renal tissue in the blendor amounted to 30 per cent of the entire kidney by weight (average amount $8.8 \mathrm{~g}$ ). The medullary particles were washed 2 to 3 times in 
abundant Gey's solution. The final suspension was injected intravenously into a forepaw vein, the plunger of a $50 \mathrm{ml}$ syringe being driven home as rapidly as possible. From the time the kidney was removed to completion of the injection, about 15 to 20 minutes was required. After the operation, the animal received one injection of penicillin (500,000 units).

No reactions occurred when washed medullary particles were infused intravenously. Experiments with whole kidney, prepared and infused intravenously in the same manner, were unsuccessful owing to pulmonary edema, anoxia, convulsions and death. Thus, cortical tissue appeared to initiate acute and lethal pulmonary complications. Twelve to 47 days after the intravenous injection (average 24 days) the right kidney was removed, and the experiment proceeded as with the other groups.

Group III: Outer medulla explanted to peritoneum. In 8 dogs the outer medulla, that is, the renal medulla exclusive of the main bulk of the papilla, was treated in the same fashion as the whole kidney and injected into the peritoneal cavity. The amount of renal tissue placed in the blendor averaged $5.6 \mathrm{~g}$. Nineteen to 33 days later (average 23 days) the right kidney was removed, and the experiment was continued as with the other groups.

Group IV: Cortex explanted to peritoneum. In 8 dogs the renal cortex was explanted to the peritoneum by the same procedure used for the whole kidney and outer medulla. In 4 of these animals the entire cortex, the zone from the vascular arcade to the capsule, was used. The amount of tissue placed in the blendor amounted to 64 to 69 per cent of the kidney by weight (average 66 per cent). In 4 animals the outer half to two-thirds of the cortex, or a portion of outer cortical tissue amounting to 40 per cent of the kidney by weight, was used. Nineteen to 42 days after the explantation (average 28 days) the opposite or right kidney was removed, and the experiment proceeded as with the other groups.

Group V: Spleen or liver explanted to peritoneum. The spleen was explanted to the peritoneum in 5 dogs, and a portion of the liver was explanted to the peritoneum in 2 dogs; at the same time the left kidneys were removed. The weight of the splenic or hepatic tissue placed in the blendor was gauged by the weight of the entire left kidney. For the spleen, the weight of tissue averaged 85 per cent of the weight of the left kidney; for the liver, an amount averaging 108 per cent of the left kidney by weight was used. Both tissues were prepared as the whole kidney was prepared. The entire spleen was removed (weight, 18.6 to $25 \mathrm{~g}$ ) from the $5 \mathrm{dogs}$, and one lobe of the liver (weight, 22.2 and $32 \mathrm{~g}$ ) was removed from the other animals. Twelve to 26 days later (average 19 days), the right kidney was removed and the experiment was conducted as for the other groups. The antibiotic mixture used in the explantation procedure to the peritoneum was tested for toxicity against monkey kidney cells and Hela cells in tissue culture. The cells were maintained for 7 days without any cytopathologic change. Similar cells in the same medium containing minimal amounts of penicillin and streptomycin served as controls.
Group VI: Bilateral nephrectomy without explantation. A group of 10 dogs was subjected to bilateral nephrectomy and then treated in the same way as the above groups with respect to diet and sodium intake. The experiments in this group were purposely interspersed among the explantation experiments ( 1 to 3 with each explantation group). This group constituted a renoprival control paired with the explantation groups. In comparing the results of the groups having renal explants with those following bilateral nephrectomy, the values obtained in the present group of 10 nephrectomized dogs were combined with the results from 28 dogs which had been similarly managed (7) . This approach was justified by the lack of a significant difference in the changes in arterial pressure between the two groups of nephrectomized animals.

Experimental protocol. Mongrel dogs (males and nonpregnant females) were used. The mean arterial pressure was measured by direct femoral artery puncture and a mercury manometer. The original control arterial pressures were obtained for 4 to 7 days before the first nephrectomy in the explantation groups, and before the nephrectomies in the renoprival group. Two to 7 weeks after the explantation, the right or opposite kidney was removed under ether anesthesia. In the interval between the nephrectomies the mean arterial pressure was taken periodically. The final control arterial pressure was taken prior to the second nephrectomy. The changes in mean arterial pressure during the 4 days subsequent to the second nephrectomy were derived by two approaches: by considering the initial control pressure as the zero control; and by considering the final control pressure as the zero control. There was no statistical difference in the two approaches of analyzing the data, apparently due to minimal changes in the arterial pressure between the nephrectomies. In this presentation, the final control arterial pressure is considered as the zero base line for evaluating the changes of the explanted groups after the second nephrectomy.

The body weight was obtained before and after the nephrectomies. Each kidney was weighed upon removal. The difference between the whole kidney weight and the tissue discarded (the capsule, that cut away, and that remaining on the sieve as a residue) was the amount treated in the blendor (see Table I). No attempt was made to determine how much renal tissue was lost in the blendor through homogenization. After the second nephrectomy, the diet consisted of a special formula, previously described (Diet no. 1) (7), which consisted of 3 to $4 \mathrm{~g}$ of protein (casein) per $\mathrm{kg}$ per day, a hypocaloric content (about 24 calories per $\mathrm{kg}$ per day) and a low electrolyte content. Physiologic saline was infused intravenously ( $16 \mathrm{ml}$ per $\mathrm{kg}$ per day). The diet and saline were given once daily. The general design of the experiment was the same as that used previously $(7,8)$. After the second nephrectomy, the mean arterial pressure was obtained twice daily about 5 to 6 hours apart for 4 days.

Morphologic protocol. Four days after the second nephrectomy the animals were sacrificed and autopsies were performed. Tissues from the viscera were fixed in 
TABLE I

Effect of whole kidney implantation on postnephrectomy hypertension*

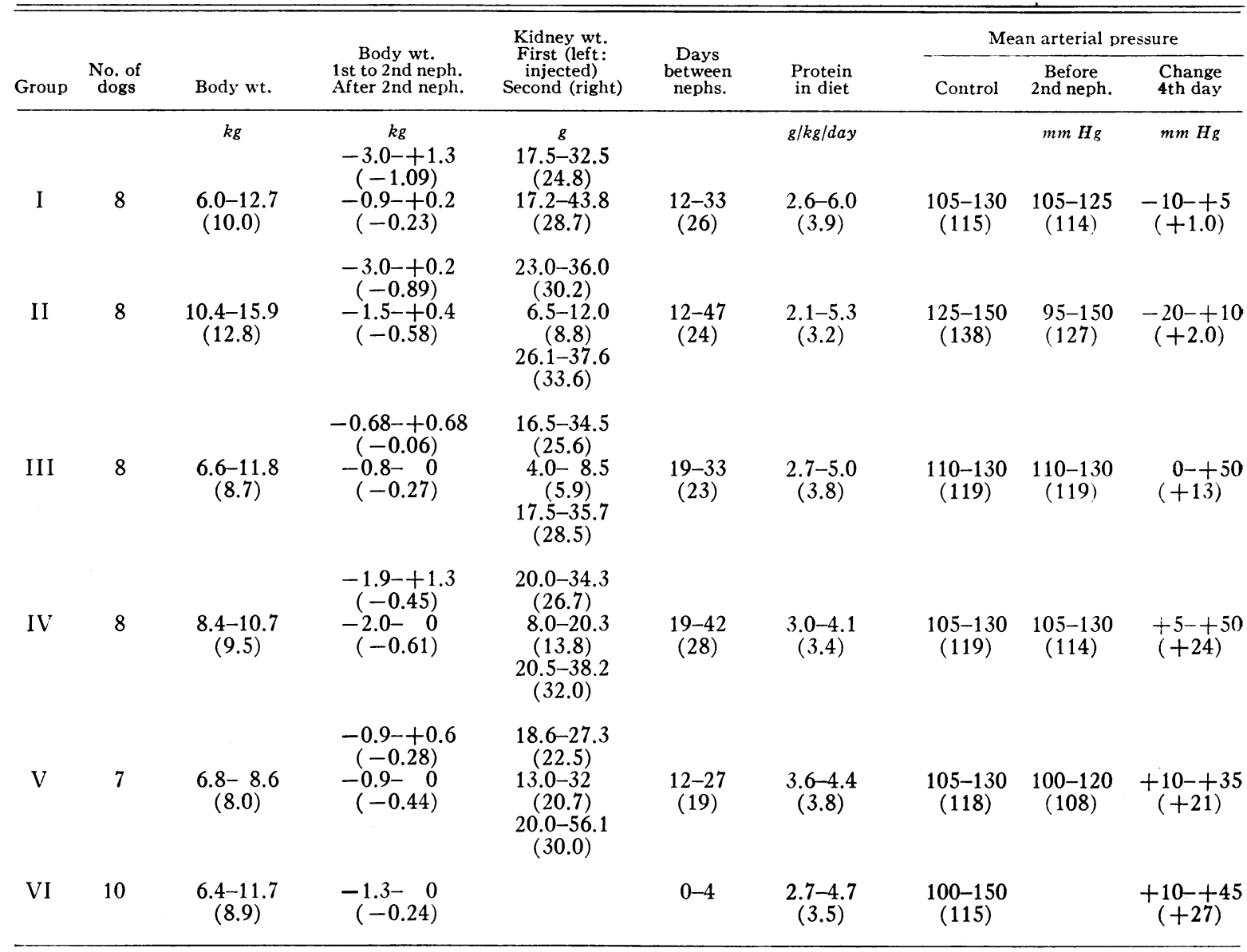

* These data summarize the main features of the various groups. The figures separated by a hyphen represent the range of the particular value while the figure in parentheses represents the corresponding mean value. By the term "injected" in column 5 is meant the amount of tissue prepared in the blendor for injection as explant. Kg $=\mathrm{kilogram}$ body weight; neph. = nephrectomy.

10 per cent neutral formalin and sections of about $5 \mu$ in thickness were stained with hematoxylin and eosin. The renal explants were also fixed in Zenker's formal for 24 hours, washed in running water for 48 hours, and then stained with crystal violet (9). In addition, the explanted tissue was stained using the periodic acid Schiff reagent procedure (PAS) (10) and Verhoeff's stain for elastic fibers (11).

\section{Technique of analysis}

Wall/lumen ratio. The state of the visceral arterioles was appraised by measurement of the ratio of the wall thickness to the diameter of the lumen as previously described $(12,13)$. An elevation of this wall/lumen ratio may be considered indicative of arteriolar thickening, a change which occurs in hypertensive cardiovascular disease (14). Measurements of the wall thickness and lumenal diameter of arterioles were obtained in a blind study. The study was confined to arterioles less than 100 $\mu$ in outside diameter in the fixed preparation as found in the heart, adrenal capsule, gastrointestinal tract, pancreas, liver, and urinary bladder.

Red blood cell survival. The survival of the erythrocytes was evaluated in their native environment over 3 days' time by means of the radiochromium method (15). Twenty $\mathrm{ml}$ of heparinized whole blood was incubated under sterile conditions with 25 to $50 \mu \mathrm{c}$ of $\mathrm{Cr}^{51}$ (specific activity $55 \mathrm{mc}$ per $\mathrm{mg} \mathrm{Cr}$ ), at $37^{\circ} \mathrm{C}$ for 30 to 45 minutes. The plasma was removed and the red cells were washed 3 times with cold sterile saline, using centrifugation. The washed erythrocytes, suspended in an equal volume of saline, were injected intravenously. The base line sample (100 per cent value) was taken 24 hours later. Thereafter, a blood sample for measurement of radioactivity was obtained each 24 hours for 3 days. Data from the explanted groups and the nephrectomized group were compared with those from a normal group of 10 dogs.

Standard laboratory procedures. The plasma urea con- 
centration was determined before the second nephrectomy and at the end of the experiment 4 days later by means of a urease method (16). The red blood cell count, hemoglobin concentration $(17)$, hematocrit reading $(18,19)$, reticulocyte count (20), white blood cell count, and platelet count (direct and indirect methods) $(20,21)$ were determined before the first nephrectomy, before the second nephrectomy, and in all but one group (explantation of renal cortex) 4 days after the second nephrectomy. On these occasions the direct antiglobulin (Coombs') test was also conducted on the circulating erythrocytes with the use of a canine antiglobulin serum prepared in rabbits in our laboratory (22).

\section{Statistical methods}

Mean arterial pressure. The change in mean arterial pressure when related to time appeared to describe a straight line. These data were fitted to a straight line function $(y=A x+b)$ by the method of least squares. The regression coefficients were tested for linearity, and the regression coefficients of each group were compared by $t$ test as described by Batson (23). The correlation coefficient calculated from the least squares fit was tested against zero by $t$ test (24).
Red blood cell survival. For the four day study period the red cell survival curve is linear. These data were tested and compared in the same manner as was the arterial pressure.

Wall/lumen ratio of arterioles. A frequency distribution plot of the wall/lumen ratio described a curve skewed to the left. Transformation, using the logarithm of the wall/ lumen ratio, produced a normal curve. A $t$ test was used to compare the means of the different groups (24).

Kidney weight. When the two kidneys in any one dog are considered as nonindependent samples, the difference between them should be zero. Comparison of the mean difference of the various groups was accomplished by $t$ test (24).

Blood urea concentration. A $t$ test was used to compare the means of the different groups (24).

\section{RESULTS}

\section{Mean arterial blood pressure}

Group I: Whole kidney explanted to peritoneum (see Figure 1, Tables $I$ and $I I$ ). When whole kidney was explanted to the peritoneum no change in

WHOLE KIDNEY EXPLANTED TO PERITONEUM

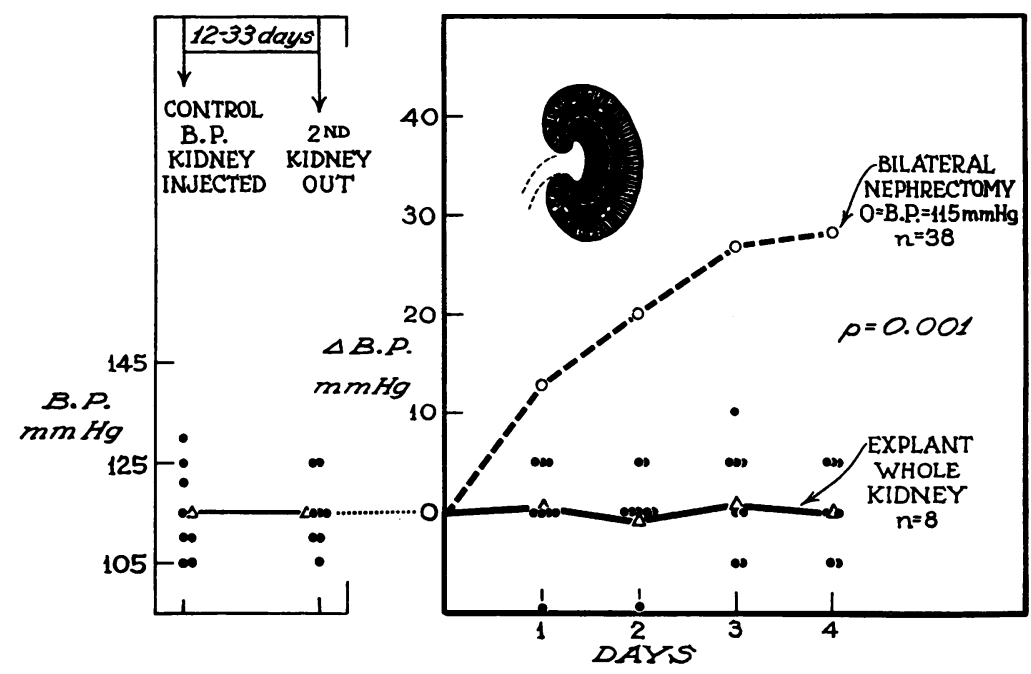

Fig. 1. Changes in the mean arterial pressure observed for Group I RECEIVING WHOLE KIDNEY EXPLANTS INTO THE PERITONEUM (8 DOGS). A comparison with the changes in arterial pressure following bilateral nephrectomy is depicted. The same general scheme is used in Figures 1 through 5. The solid line represents the average arterial pressure for the explantation group. The broken line represents the average pressure following bilateral nephrectomy (38 dogs). The panel on the left relates a scattergram and average value of the mean arterial pressure before the first nephrectomy and explantation and the pressure before the second nephrectomy (in this case 12 to 33 days later). The panel on the right relates a scattergram and average of the changes in the mean arterial pressure for the four days following the second nephrectomy. The black portion of the inset indicates the area of renal tissue explanted. The " $p$ " value was derived by an analysis of slopes fitted to the data of the explanted and the nephrectomized groups. 
TABLE II

Statistical analysis of the changes in mean arterial pressure

\begin{tabular}{|c|c|c|c|c|c|}
\hline Group & $\begin{array}{l}\text { No. of } \\
\text { dogs }\end{array}$ & Slope & $\mathrm{SE}$ & $\begin{array}{c}\text { p } \\
\text { Slope vs. } \\
\text { zero }\end{array}$ & $\begin{array}{l}\mathrm{p} \\
\text { Group vs. } \\
\text { Group VI }\end{array}$ \\
\hline & & $m m / d a y$ & & & \\
\hline I & 8 & 0.336 & 0.79 & 0.9 & 0.001 \\
\hline II & 8 & -1.188 & 1.53 & 0.2 & 0.001 \\
\hline III & 8 & 3.558 & 0.91 & 0.001 & 0.04 \\
\hline IV & 8 & 6.191 & 1.33 & 0.001 & 0.9 \\
\hline V & 7 & 3.055 & 1.31 & 0.001 & 0.1 \\
\hline VI & 10 & 6.296 & 1.00 & 0.001 & \\
\hline
\end{tabular}

the mean arterial pressure occurred following removal of the second kidney. The average mean arterial pressure for the group was $115 \mathrm{~mm} \mathrm{Hg}$ before the first nephrectomy, and remained the same 12 to 33 days later, and prior to the second nephrectomy. After the second nephrectomy this average value also remained the same. A slope fitted to these data yielded no significant difference when compared to zero $(p=0.9)$. Following bilateral nephrectomy and the same intake of sodium, water, protein and calories, the mean arterial pressure was sharply elevated (average increment of mean pressure over control $+28 \mathrm{~mm} \mathrm{Hg}$ ). A slope fitted to these data yielded a significant difference from zero $(p=0.001)$. Analysis of the slopes fitted to the data on the arterial pressure of Group I (whole kidney explants) and the ne- phrectomized groups, demonstrates a significant difference between these two groups $(p=0.001)$. Thus, whole kidney explantation appeared to protect against accelerated hypertension occurring under these circumstances.

Group II: Renal medulla explanted to lungs (see Figure 2, Tables $I$ and II). Renal medulla explanted to the lungs was associated with a slight elevation of the average value of the arterial pressure for the entire group during the first two days due to early and transient hypertension in two dogs. This was followed by return of the average value to the base line. The slope of the line was not significantly different from zero $(p=0.2)$. The statistical difference between the regression coefficient of the line for the bilateral nephrectomy group and the group with medullary explants to the lungs was significant $(p=0.001)$. Thus, explanted renal medulla also appeared to protect against the accelerated hypertension of bilateral nephrectomy.

Group III: Outer medulla explanted to peritoneum (see Figure 3, Tables, I and II). When outer medulla was explanted to the peritoneum, the slope derived from the change in arterial pressure over the control value was significantly different from zero $(p=0.001)$. This finding indicates an elevation in the arterial pressure for this group.

\section{RENAL MEDULLA EXPLANTED TO LUNGS}

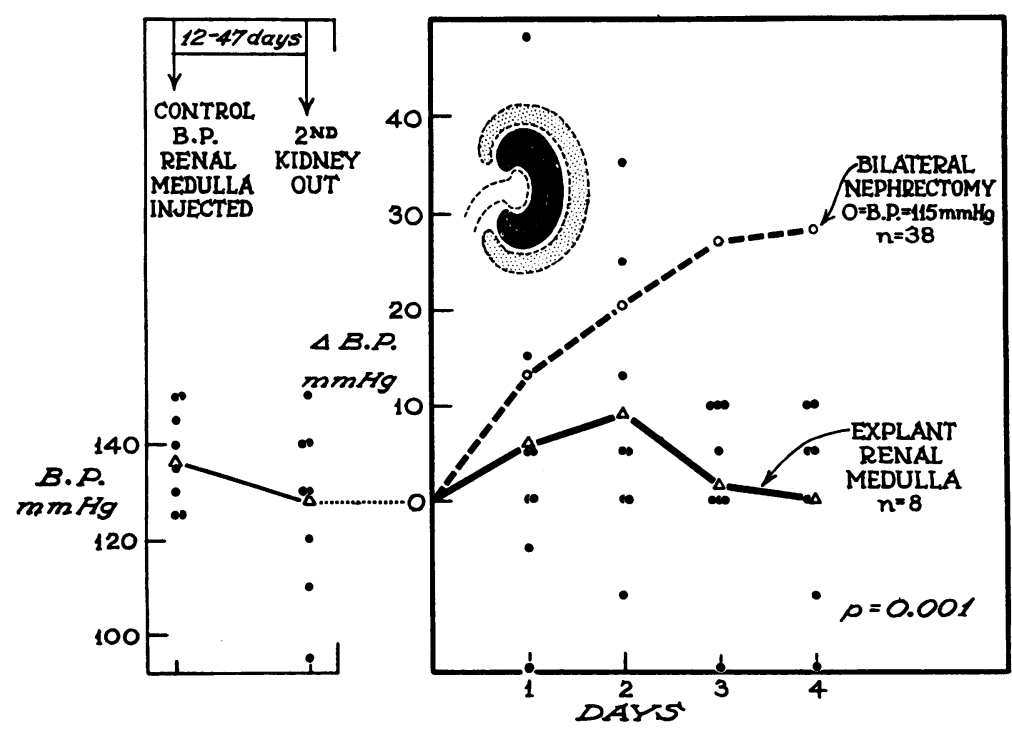

Fig. 2. Changes in mean arterial pressure observed for Group II ReCEIVING EXPLANTS OF WHOLE RENAL MEDULLA INTO LUNGS. 


\section{OUTER RENAL MEDULLA EXPLANTED TO PERITONEUM}

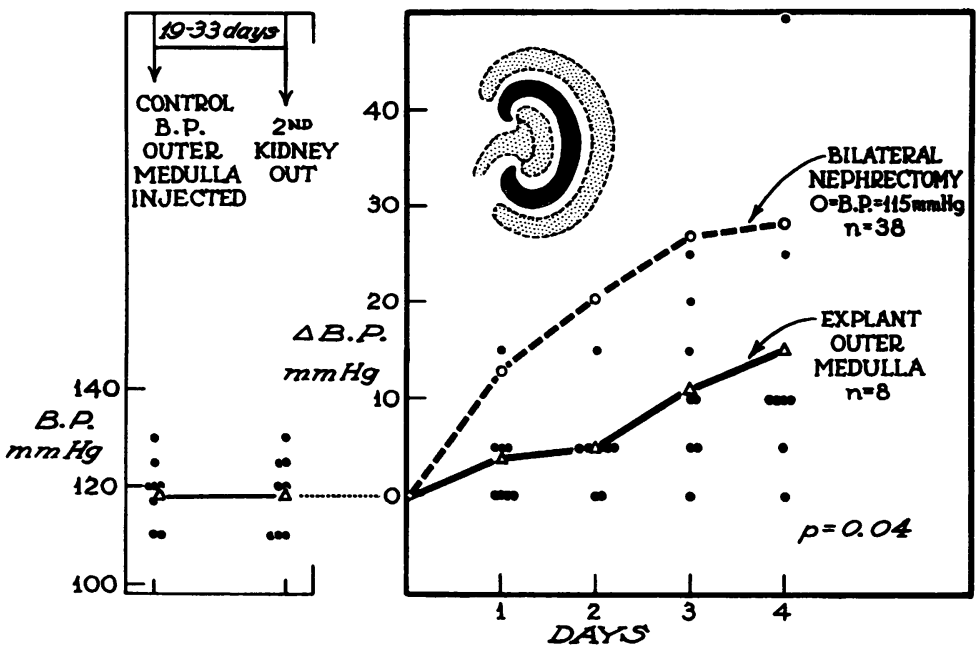

Fig. 3. Changes in mean arterial pressure observed for Group III ReCEIVING EXPLANTS OF OUTER RENAL MEDULLA INTO PERITONEUM.

However, when the slope of the outer medulla group was compared with that following bilateral nephrectomy, a significant difference remained $(p=0.04)$. The observations may be taken to indicate that outer renal medulla explanted in this fashion is partly protective against the hypertension.

Group IV: Renal cortex explanted to peritoneum (see Figure 4, Tables I and II). When the entire renal cortex or the outer portion of the cortex was explanted to the peritoneum, no protection against hypertension occurred upon removal of the second kidney and the intake of sodium and dietary protein (slope vs. zero, $\mathrm{p}=$ 0.001 ). Analysis of the slopes derived from the changes in arterial pressure for this group and the nephrectomized group revealed no significant difference $(\mathrm{p}=0.9)$.

Group V: Spleen or liver explanted to peritoneum (see Figure 5, Tables $I$ and II). This group was not protected against hypertension ( $\mathrm{p}$ vs. zero 0.001 ; vs. bilateral nephrectomy 0.1 ).

RENAL CORTEX EXPLANTED TO PERITONEUM

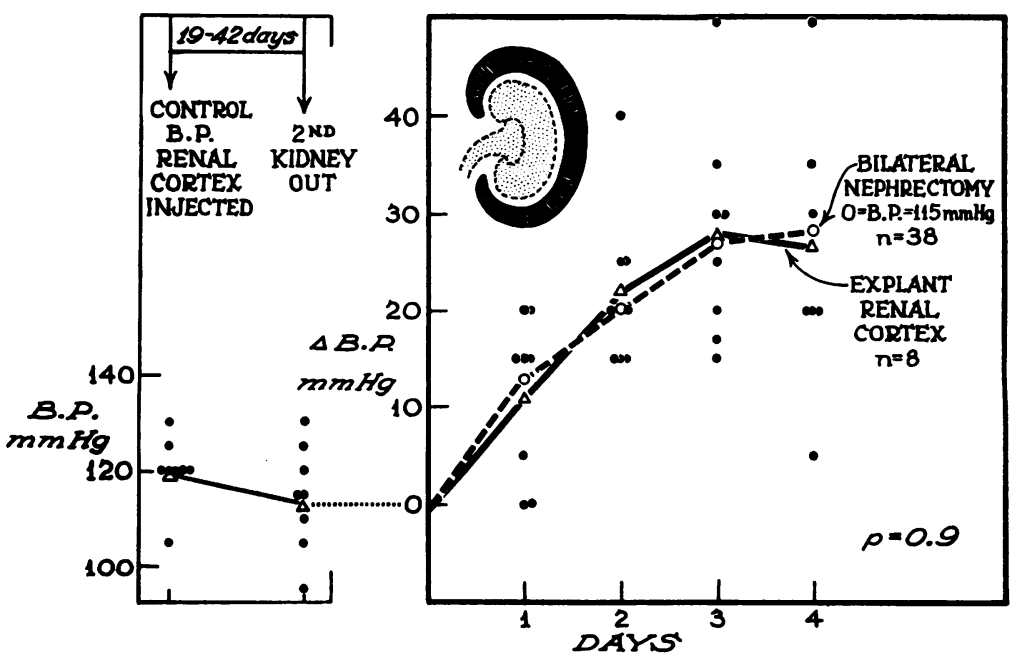

Fig. 4. Changes in Mean arterial pressure for Group IV ReCeiving eXPLANTS OF RENAL CORTEX INTO PERITONEUM. 


\section{SPLEEN-(5) OR LIVER-(2) EXPLANTED TO PERITONEUM}

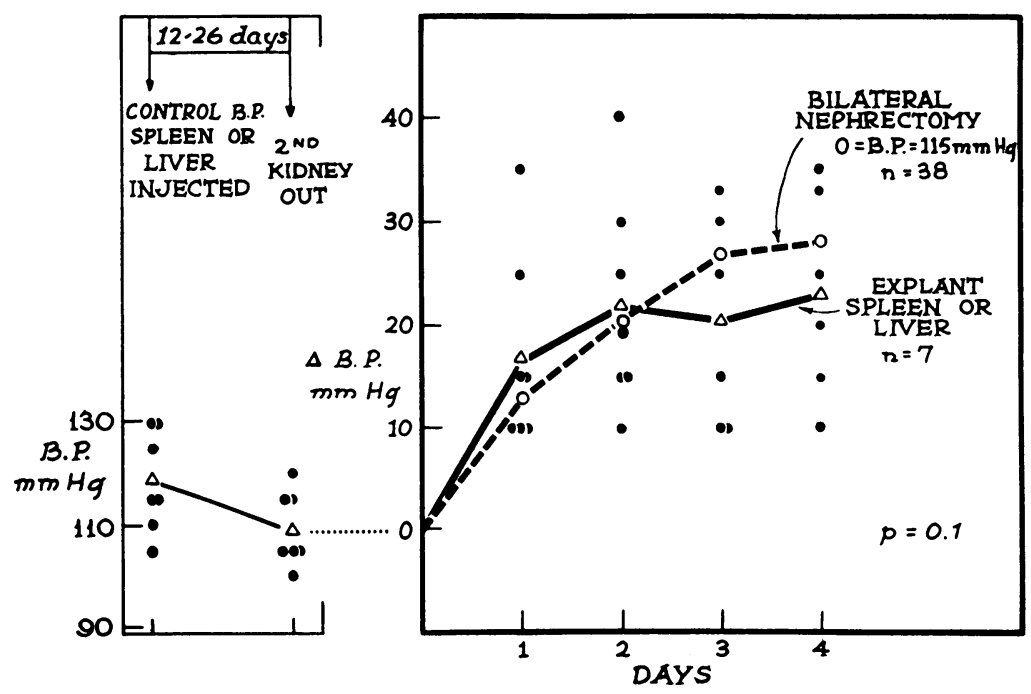

Fig. 5. Changes in mean arterial pressure for Group V receiving exPLANTS OF SPLEEN OR LIVER INTO PERITONEUM.

Body weight (Table I). During the interval between nephrectomies, 13 of the 24 animals in the groups receiving explants of whole kidney or renal medulla, Groups I, II and III, lost weight $(-0.9$ to $-3.0 \mathrm{~kg})$, while 11 animals either gained weight or lost none $(0$ to $+1.3 \mathrm{~kg})$. Following the second nephrectomy, most of these animals lost a slight amount of weight during the four days of observation (average -0.2 to -0.57 $\mathrm{kg})$. Of the 15 animals in the groups receiving explants of renal cortex, spleen, or liver, eight lost weight $(-0.4$ to $-1.9 \mathrm{~kg})$ between the nephrectomies while seven either gained weight or lost none $(0$ to $+1.3 \mathrm{~kg})$. After the second nephrectomy the weight loss was comparable to that of the other groups (average -0.4 and $-0.6 \mathrm{~kg}$ ). The average weight loss during the four days following bilateral nephrectomy of Group VI was

TABLE III

Statistical analysis of the data on the wall/lumen ratio of arterioles

\begin{tabular}{|c|c|c|c|c|c|}
\hline \multirow[b]{2}{*}{ Group } & \multirow[b]{2}{*}{$\begin{array}{l}\text { No. of } \\
\text { arteri- } \\
\text { oles }\end{array}$} & \multirow[b]{2}{*}{$\begin{array}{c}\log \\
(\operatorname{meanWW} / \mathrm{L} \\
\times 10)\end{array}$} & \multirow[b]{2}{*}{ SE } & \multicolumn{2}{|c|}{ p } \\
\hline & & & & $\begin{array}{c}\text { Group } \\
\text { vs. } \\
\text { normal }\end{array}$ & $\begin{array}{l}\text { Group } \\
\text { vs. } \\
\text { Group VI }\end{array}$ \\
\hline Normal & 499 & 0.6042 & 0.00939 & & 0.001 \\
\hline I & 353 & 0.6430 & 0.0136 & 0.02 & 0.001 \\
\hline IV & 365 & 0.6953 & 0.01410 & 0.001 & 0.04 \\
\hline VI & 383 & 0.7405 & 0.0138 & 0.001 & \\
\hline
\end{tabular}

$-0.24 \mathrm{~kg}$. From these data it appears that the state of the body weight did not bear directly on the state of the mean arterial pressure since lack of hypertension and the presence of hypertension were about equally distributed among animals losing. gaining, or having steady body weight.

Weight of kidneys (Tables $I$ and $V$ ). The right kidney (obtained at the second nephrectomy) weighed more than the left kidney in 19 of the 24 observations of Groups I, II, and III combined. The mean difference of all 24 observations was $+3.43 \mathrm{~g}$. The right kidney of all $15 \mathrm{dogs}$ in Groups IV and V combined, weighed more than the left. The mean difference was $+6.47 \mathrm{~g}$. The weight of the kidneys from 16 normal dogs in the type of colony used in the experiments was obtained after bilateral nephrectomy performed at the same time. In these cases the right kidney usually weighed slightly more than the left kidney. The mean difference was $+0.513 \mathrm{~g}$. In Table $\mathrm{V}$ it may be noted that the differences in kidney weight between combined Groups I, II, and III, and Groups IV and V, and the normal group were significant. Moreover, the difference between Groups I, II, and III, and Groups IV and V was also significant. These data indicate a greater degree of hypertrophy of the remaining kidney in groups which subsequently became hypertensive (Groups IV and V) than was observed with the 
groups which were protected against the hypertension (Groups I, II, and III). This observation implies partial protection by the explants containing renal medulla against hypertrophy during the 19 to 28 days of observation.

Wall/lumen ratio of visceral arterioles (Table $I I I)$. The wall/lumen ratio of visceral arterioles was increased over the normal in all groups. By this approach a disparity seemed to exist between the degree of protection against hypertension and protection against arteriolar change. Analysis of the data, however, suggests some protection against arteriolar thickening by whole kidney explants. Thus, the results from Group I (whole kidney explantation) were nearer the normal than the results from the other groups, while also markedly different from those of Group VI (bilateral nephrectomy); and the results from Group IV (renal cortex explantation) were markedly different from the normal and to a greater extent approximated those following bilateral nephrectomy than did the results from Group I.

Survival of erythrocytes (Figure 6 and Table $I V)$. The slope of disappearance of radioactivity from the peripheral blood over the three days of observation when erythrocytes were tagged with radiochromium was not different when the group with whole kidney explants was compared with the normal $(p=0.6)$. The slope of disappearance of radioactivity following bilateral nephrectomy and following explantation of the renal cortex did not differ from each other $(p=0.6)$, while both of these slopes differed from the normal group and the group receiving whole kidney explants $(p=0.001$ and $<0.001)$. Explanation of the renal medulla was partly protective toward the hemolytic state. The slope derived from the changes in radioactivity following explantation of renal medulla was not different from that following whole kidney explantation $(p=0.2)$, but it differed from that obtained from normal dogs ( $p=$ 0.02 ), and that obtained following explantation of renal cortex $(\mathrm{p}=0.001)$.

Azotemia (Table VI). Prominent azotemia was observed on the fourth day following the second nephrectomy in all groups. The level of azotemia observed in Groups III and IV was not different from that following bilateral nephrectomy

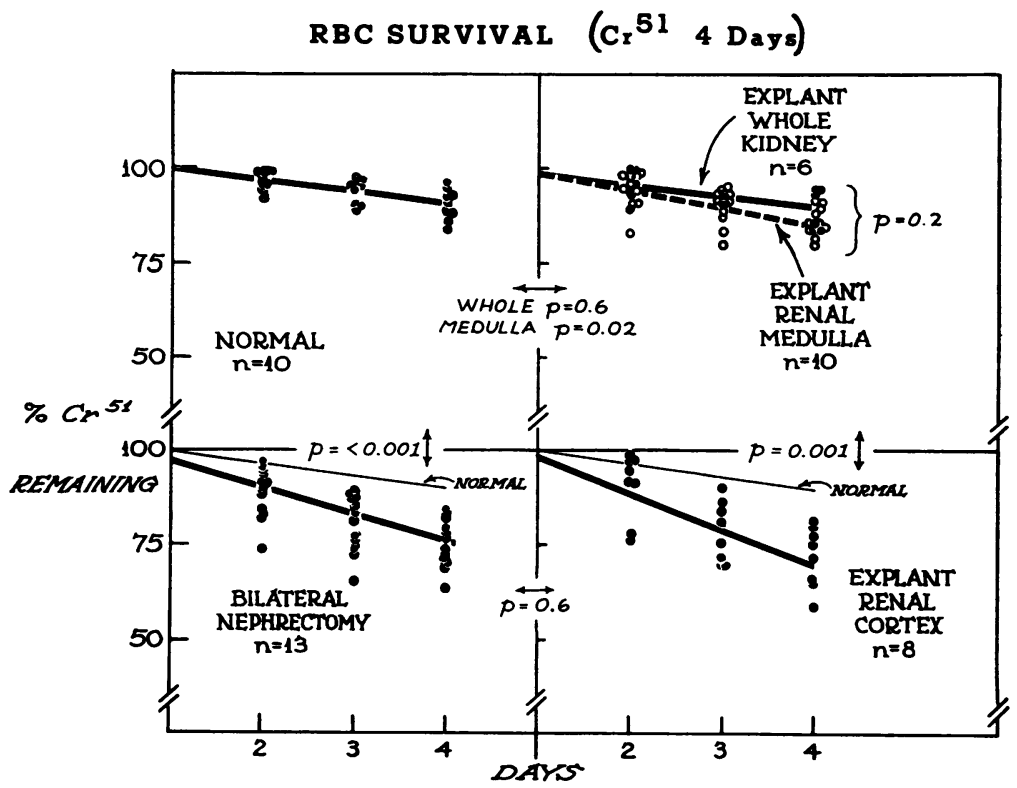

Fig. 6. RESUlts OF SURVIVAL OF ERYTHROCYTES OVER THE FOUR DAYS OF OBSERVATION AS DERIVED WITH THE RADIOCHROMIUM METHOD. A scattergram of the remaining radioactivity of $\mathrm{Cr}^{51}$ for Days 2, 3 and 4 is depicted, utilizing the value of Day 1 as the 100 per cent reference. The solid line represents the best fit for the data. The "p" were derived by comparing these slopes. The arrows indicate which groups are being compared. For convenience the normal slope is reproduced in the two lower panels. 
TABLE IV

Statistical analysis of the data on red blood cell survival

\begin{tabular}{|c|c|c|c|c|c|}
\hline Group & $\begin{array}{c}\text { No. of } \\
\text { dogs }\end{array}$ & Slove & $\mathrm{SE}$ & $\begin{array}{c}\mathrm{p} \\
\text { Group vs. } \\
\text { normal }\end{array}$ & $\begin{array}{l}\mathrm{p} \\
\text { Group v's. } \\
\text { Group VI }\end{array}$ \\
\hline & & $-\% / d a y$ & & & \\
\hline Normal & 10 & 3.174 & 0.428 & & 0.001 \\
\hline I & 6 & 3.52 & 0.67 & 0.6 & 0.001 \\
\hline II, III & 10 & 4.69 & 0.498 & 0.02 & 0.005 \\
\hline IV & 8 & 9.49 & 1.123 & 0.001 & 0.1 \\
\hline VI & 13 & 7.02 & 0.513 & 0.001 & \\
\hline
\end{tabular}

alone (Group VI). There was a suggestive difference in the level of azotemia between Groups I and II and the nephrectomized group (Group VI). It is to be noted that Groups I and II were well protected against the hypertension while Group IV was not protected and Group III was only partly so.

Hematologic obscrvations. With rare exceptions, slight or no anemia occurred between the nephrectomies (Table VII). After the second nephrectomy, the animals in Groups I, II, and III displayed slight or no anemia as a group. Four animals of the 24 became prominently anemic. All seven dogs in Group $\mathrm{V}$ became prominently anemic after the second nephrectomy. The erythrocytes in general remained normochromic and the cell size remained unchanged. The percentages of reticulocytes remained in the normal range in most instances. The direct Coombs' test remained negative throughout the entire study. The white cell count was usually elevated after the second nephrectomy. The platelet count remained in the normal range for all groups except for the two dogs that received explants of liver and became thrombocytopenic.

Morphologic features of explants. The peritoneum was studded with grey and grey-brown granules in the animals in Groups I. III, and IV.

TABLE V

Statistical analysis of the difference in kidney weight*

\begin{tabular}{|c|c|c|c|c|c|}
\hline Group & $\begin{array}{c}\text { No. of } \\
\text { dogs }\end{array}$ & $\begin{array}{l}\text { Mean } \\
\text { dif. }\end{array}$ & $\mathrm{SE}$ & Vs. normal & $\begin{array}{l}\text { p } \\
\text { Vs. Groups } \\
\text { IV, V }\end{array}$ \\
\hline $\begin{array}{l}\text { Normal } \\
\text { I, II, III } \\
\text { IV, V }\end{array}$ & $\begin{array}{l}16 \\
24 \\
15\end{array}$ & \begin{tabular}{l}
\multicolumn{1}{c}{$g$} \\
0.513 \\
3.43 \\
6.47
\end{tabular} & $\begin{array}{l}0.296 \\
0.827 \\
1.070\end{array}$ & $\begin{array}{l}0.001 \\
0.001\end{array}$ & 0.001 \\
\hline
\end{tabular}

* The right kidney weighed more than the left kidney in the mean difference.
TABLE VI

Statistical analysis of the change in plasma urea concentration*

\begin{tabular}{lccccc}
\hline Group & $\begin{array}{c}\text { No. of } \\
\text { dogs }\end{array}$ & $\begin{array}{c}\text { Mean } \\
\text { control }\end{array}$ & $\begin{array}{c}\text { Mean } \\
\text { 4 days }\end{array}$ & SE & $\begin{array}{c}\text { p } \\
\text { Group vs. }\end{array}$ \\
\hline I & 5 & 48 & 210 & 23.2 & 0.07 \\
II & 5 & 49 & 228 & 10.9 & 0.07 \\
III & 5 & 52 & 299 & 28.5 & 0.6 \\
IV & 5 & 51 & 312 & 13.7 & 0.2 \\
VI & 5 & 46 & 276 & 22.1 &
\end{tabular}

* Given in milligrams per $100 \mathrm{ml}$.

The granules varied in size from 1 to $10 \mathrm{~mm}$. These foci were most abundant in the omentum and mesentery and on the under surface of the diaphragm (Figure 7). Foci were also observed on the surface of the spleen, on the colon, and on the liver. Microscopically, the explants of Group I contained hyaline foci surrounded by viable-appearing epithelial cells. These cells formed tubules and irregular clumps embedded in a vascular stroma (Figures 8 and 9). The hyaline foci consisted of hyalinized glomeruli and structures that appeared to be collapsed and compressed basement membranes of tubules. The most common cell type displayed a clear cytoplasm. Rarely. a mitotic figure involving these epithelial cells was observed. The PAS-stained tissues supported the view that collapsed basement membranes were present. These structures were PAS-positive and had a compressed, undulated configuration. These observations indicated resorption of the convoluted tubes. The arterioles near

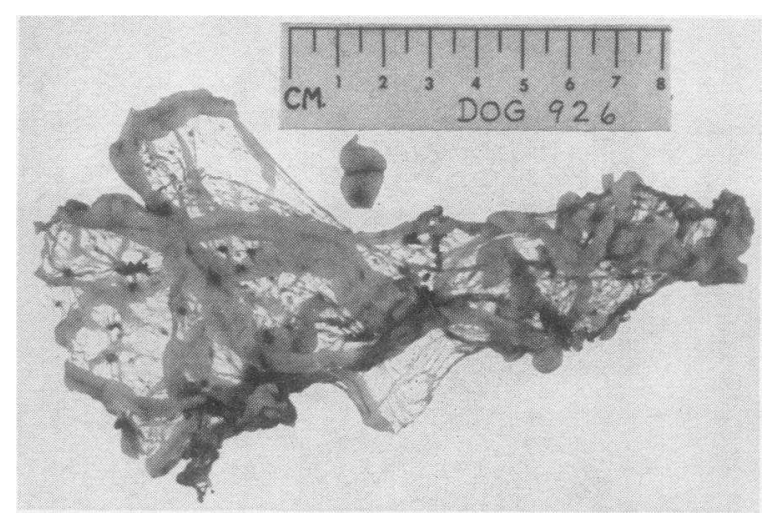

Fig. 7. OMENTUM FROM DOG 37 days FOllowing EXPLANTATION OF WHOLE KIDNEY, OBTAINED BY TRANSILLUmination. Granules of various sizes are shown in the omentum. These are the structures that contain viableappearing cells. 


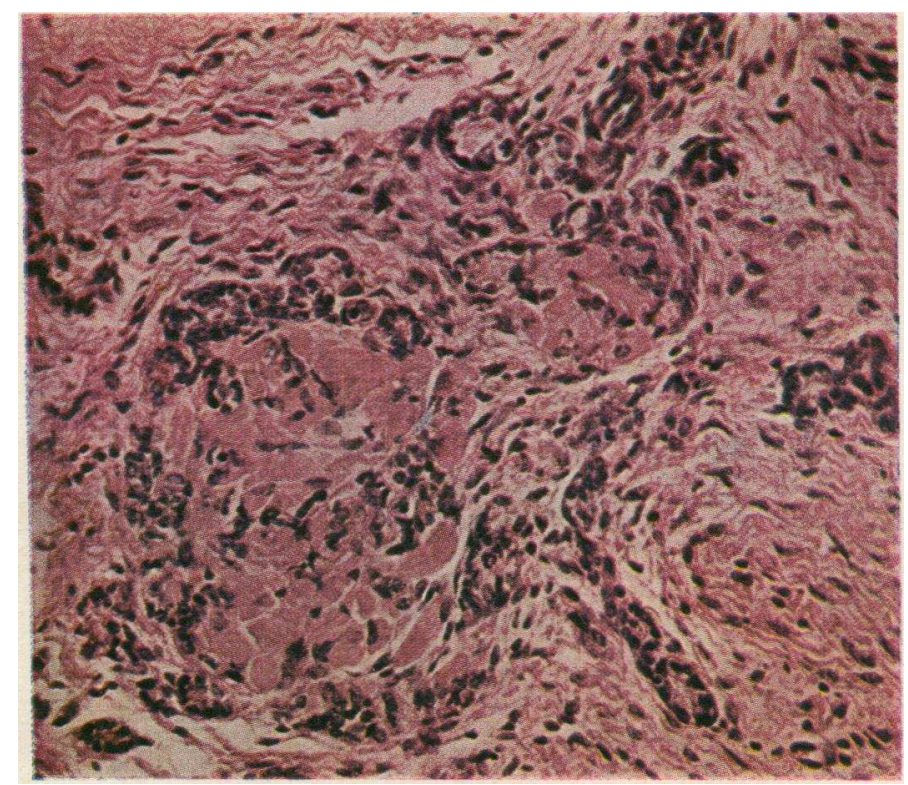

Fig. 8. Microscopic SEgment of a GRANUle ( $\times 260$; HemaTOXYLIN AND EOSIN STAIN) AS NOTED IN FIG. 7. The pink hyaline foci are interpreted as collapsed basement membranes of resorbed tubules. About these foci are noted tubules and clusters of epithelial cells.

the glomeruli revealed atrophy of the smooth muscle of the media and reduplication of the internal elastic lamina as indicated by the Verhoeff elastic stain. Attempts to identify juxtaglomerular cells in the arterioles near the glomeruli with the crystal violet stain were not successful. Thus, the cortex seemed to undergo widespread atrophy and resorption of all of its structure.

Atrophy and resorption of cortical tissue were emphasized in the explants of Group IV (cortex

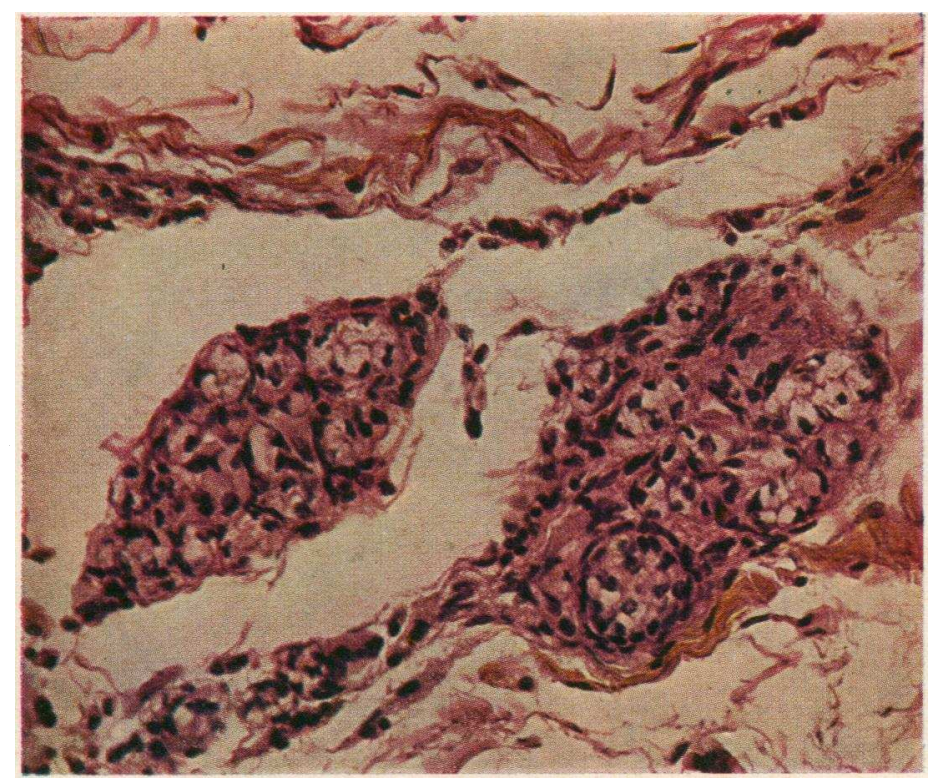

Fig. 9. Clusters of Clear epithelial cells in the omentum. This was the most common cell type observed. 


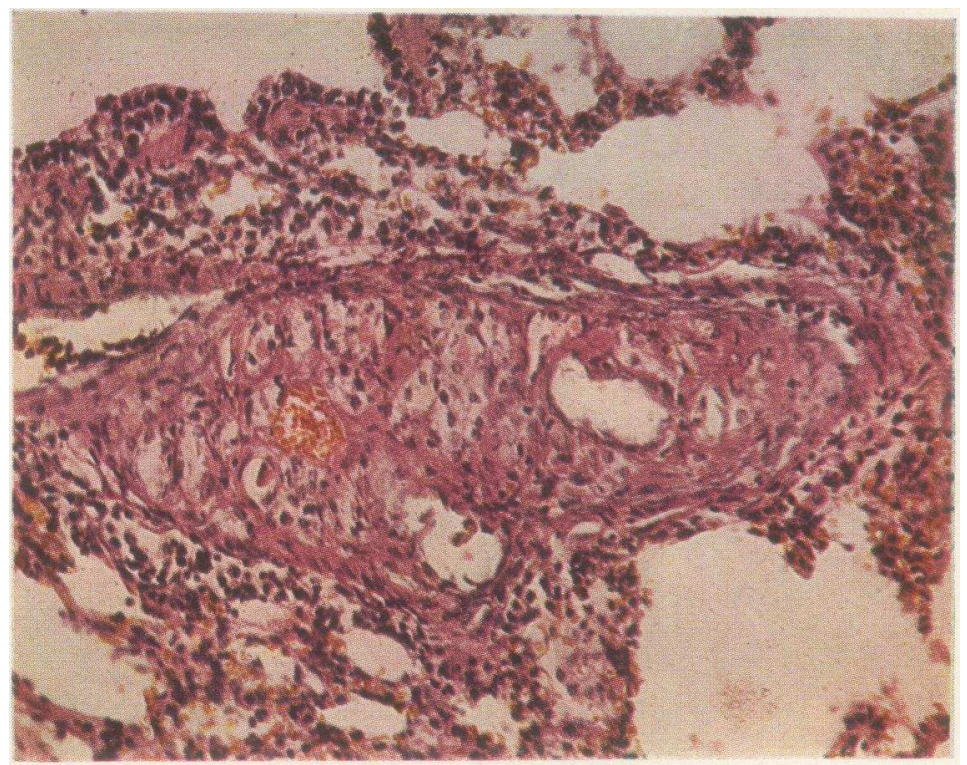

Fig. 10. Explant of Renal medulla in the lung. A vascular branch, presumably arterial, is filled with clear epithelial cells in clusters or forming tubules. This is the same cell type as that observed over the peritoneum.

only). There were few viable-appearing cells in these nodules and these few cells appeared to belong to atrophic convoluted tubules. Clear cells were very rarely encountered in these explants. The explants of Group III were small ( 1 to $5 \mathrm{~mm}$ in diameter) and difficult to find. These structures contained mainly tubules and clumps of clear cells.

The lungs of Group II revealed scattered gray foci grossly, 1 to $4 \mathrm{~mm}$ in size, and a rare small infarct. Most areas of the lungs appeared normal grossly. Microscopically, the lungs of Group II contained hyaline emboli in branches of the pulmonary artery and focal thickening of the alveolar walls. Most alveolar spaces were empty, and most alveolar walls were normal. Within blood vessels, masses of renal epithelium were identified. These formed tubules and sheets of cells, most of which were of the clear type (Figure 11). In some areas the epithelium appeared to have broken through the vascular wall and spread out in the nearby pulmonary tissue. Certain of these areas were cellular, and a distinction between cells due to local pneumonitis and cells from renal tissue was not clear-cut. The hyaline emboli also contained clumps and clusters of clear epithelial cells.

The splenic explants of Group $V$ were evident over the peritoneal surfaces, particularly over the omentum and mesentery. Grossly, these appeared to be vascular. Microscopically, they consisted of endothelial lined sinusoids and other cells resembling reticuloendothelial cells. The hepatic explants were mostly necrotic. A few bilirubin stained cells remained.

\section{DISCUSSION}

The classical experiment of Goldblatt, Lynch. Hanzal and Summerville (25), demonstrating the development of sustained hypertension following partial constriction of a renal artery and removal of the opposite kidney of the dog, was followed by support for the concept which considered the liberation into the blood stream of a vasopressive agent from the kidney as responsible for the elevation of the arterial pressure. Notable among observations in this area were those of Braun-Menendez and associates (26), and Page (27). The earlier concept of renin (25) was expanded into the more complex view of hypertensin or angiotonin (angiotensin). The role of such substances in prolonged hypertension has been challenged. However, as Floyer's review (28) indicates, the contribution of renin to certain types of hypertension and to the early phases of experimental hyperten- 
sion appears to have been strengthened by more recent as well as by earlier considerations of this proposal.

While experiments dealing with a positive contribution of the kidney toward the genesis of hypertension were in progress, the possibility of antihypertensive functions of renal origin were entertained as a consequence of experimental results inconsistent with the renin hypothesis. The concept has been reviewed by Grollman (29), who has supported the view that the kidney elaborates a substance, possibly of a hormonal nature, which protects against hypertension.

The demonstration of a high incidence of hypertension following bilateral nephrectomy by BraunMenendez and von Euler (30) for the rat, and by Grollman, Muirhead and Vanatta (1) for the dog, lent additional emphasis to a possible renal antihypertensive function. This type of hypertension, termed renoprival, was soon corroborated by other workers $(6,31-33)$. A potentiating role toward renoprival hypertension by overhydration with sodium and water $(6,31-35)$, by sodium without overhydration (36), and by dietary protein $(7,37)$, seemed apparent as work in this field progressed. Grollman, Turner, Levitch and Hill (38) demonstrated a hemodynamic state in renoprival hypertension that was similar to that of essential hypertension in man. Turner and Grollman (39) also demonstrated a lack of dependency of the hypertension on secretions from the adrenal glands, since bilateral adrenalectomy did not prevent elevation of the arterial pressure. In other observations Muirhead, Jones and Graham (37, 40) demonstrated that the hypertension of bilateral nephrectomy was neither entirely dependent on an exogenous sodium load nor on an evident expansion of the extracellular fluid volume.

Earlier, Grollman and co-workers (1) showed protection against hypertension by renal tissue incapable of urinary excretion to the outside of the body. In these experiments the following manipulations were used: ureteral ligation, anastomosis of the ureter to the vena cava, and anastomosis of the ureter to the small bowel. The effectiveness of uretero-caval anastomosis in this respect was confirmed by Kolff, Page and Corcoran (41).

Utilizing two separate approaches. Kolff and Page (42), and Muirhead, Stirman, I,esch and Jones (12) demonstrated a recession of renoprival hypertension when the circulation of the hypertensive animal was connected to intact renal tissue. Kolff and Page perfused the circulation of the nephrectomized hypertensive animal through the intact kidneys of a normal animal, a procedure which promptly lowered the arterial pressure. Muirhead and colleagues demonstrated a prompt and sustained lowering of renoprival hypertension by the placement of a renal homotransplant in the neck of the hypertensive nephrectomized recipient. As the transplanted kidney deteriorated one week later, the hypertensive state recurred. These experiments with renal homotransplants also suggested protection by renal tissue against arteriolar disease (13).

Amelioration of the hypertensive state by a renal homotransplant in man has been shown by Merrill, Murray, Harrison and Guild (43) in the case of a hypertensive subject who received a renal transplant from his identical twin. The effectiveness of renal transplants in lowering the arterial pressure in other forms of experimental hypertension (figure-of-eight tie of kidney) has been presented by Blaquier, Gomez and Hoobler (44).

Muirhead, Stirman and Jones (45) repeated the experiment wherein one ureter was anastomosed to the inferior vena cava, and the opposite kidney was removed, by changing it into an acute experiment in which the intake of sodium and protein was controlled. The sodium intake, dietary protein intake, and the time interval of four days were the same as in the experiments recorded in the present communication. Protection against accelerated hypertension over the four days' time was observed in 16 experiments of this type. During the same time interval, the kidney with the uretero-caval anastomosis underwent an outstanding degree of hypertrophy, the average weight increment over its partner being 60 per cent. Study of this hypertrophied kidney indicated a normal anatomical configuration associated with an increase in the nonaqueous, nonlipid residue (46). The latter findings supported a true hypertrophy as opposed to waterlogging of the tissues. Mitotic figures were evident in this hypertrophied kidney and the mitoses were most numerous in the outer zone of the medulla below the vascular arcade. There was, therefore, the theoretical possibility that the zone which seemed to reflect maximum 
TABLE VII

Summary of red cell count, hemoglobin and hematocrit*

\begin{tabular}{|c|c|c|c|c|c|c|c|}
\hline Group & Tests & $\begin{array}{l}\text { Control } \\
\text { range }\end{array}$ & Average & $\begin{array}{l}\text { Prior 2nd } \\
\text { neflh. }\end{array}$ & Average & $\begin{array}{l}4 \text { days } \\
\text { after }\end{array}$ & Average \\
\hline I & $\begin{array}{l}\text { RBC } \\
\text { Hgb. } \\
\text { Hemat. }\end{array}$ & $\begin{array}{c}5-7 \\
12-18 \\
41-55\end{array}$ & $\begin{array}{l}6.3 \\
14 \\
46\end{array}$ & $\begin{array}{c}4-6 \\
8-15 \\
29-50\end{array}$ & $\begin{array}{l}5.0 \\
12 \\
.38\end{array}$ & $\begin{array}{c}4-6 \\
7-15 \\
24-53\end{array}$ & $\begin{array}{l}5.0 \\
11 \\
37\end{array}$ \\
\hline II & $\begin{array}{l}\text { RBC } \\
\text { Hgb. } \\
\text { Hemat. }\end{array}$ & $\begin{array}{c}4-6 \\
11-16 \\
35-53\end{array}$ & $\begin{array}{l}5.6 \\
14 \\
46\end{array}$ & $\begin{array}{c}4-6 \\
10-16 \\
32-49\end{array}$ & $\begin{array}{l}5.3 \\
14 \\
44\end{array}$ & $\begin{array}{c}4-7 \\
8-16 \\
30-47\end{array}$ & $\begin{array}{l}5.5 \\
12 \\
39\end{array}$ \\
\hline III & $\begin{array}{l}\text { RBC } \\
\text { Hgb. } \\
\text { Hemat. }\end{array}$ & $\begin{array}{c}5-8 \\
11-20 \\
38-56\end{array}$ & $\begin{array}{l}6.0 \\
15 \\
45\end{array}$ & $\begin{array}{c}5-6 \\
11-1.5 \\
31-47\end{array}$ & $\begin{array}{l}5.5 \\
14 \\
42\end{array}$ & $\begin{array}{c}4-6 \\
9-12 \\
27-40\end{array}$ & $\begin{array}{l}5.3 \\
11 \\
34\end{array}$ \\
\hline IV & $\begin{array}{l}\text { RBC } \\
\text { Hgb. } \\
\text { Hemat. }\end{array}$ & $\begin{array}{c}5-7 \\
12-18 \\
37-49\end{array}$ & $\begin{array}{l}5.6 \\
14 \\
42\end{array}$ & $\begin{array}{c}5-6 \\
10-15 \\
29-46\end{array}$ & $\begin{array}{l}5.6 \\
1.3 \\
38\end{array}$ & & \\
\hline V & $\begin{array}{l}\text { RBC } \\
\text { Hgb. } \\
\text { Hemat. }\end{array}$ & $\begin{array}{c}5-6 \\
12-15 \\
36-47\end{array}$ & $\begin{array}{l}5.5 \\
14 \\
44\end{array}$ & $\begin{array}{c}4-6 \\
8-15 \\
26-44\end{array}$ & $\begin{array}{l}5.0 \\
11 \\
34\end{array}$ & $\begin{array}{c}2-4.5 \\
6-11 \\
19-32\end{array}$ & $\begin{array}{l}3.7 \\
8.5 \\
26\end{array}$ \\
\hline
\end{tabular}

${ }^{*} \mathrm{RBC}=$ red cell count in millions per cubic millimeter $\mathrm{Hgb} .=$ hemoglobin concentration in grams per $100 \mathrm{ml}$; Hemat. = hematocrit reading in percentage.

proliferation or hyperplasia might be the zone related to the protection against hypertension.

These various observations, indicating protection against hypertensive cardiovascular disease by intact renal tissue incapable of the external excretion of urine, led to the currently reported experiments. The present experiments indicate protection against accelerated renoprival hypertension by explanted autogenous renal tissue which is incapable of excretory renal function from the physiologic viewpoint. Whole kidney explantation appeared most protective while renal cortex was nonprotective. Whole renal medulla seemed to offer substantial protection against the hypertension while the outer medulla was protective, but only to a lesser extent. The net results seem to indicate that the function which appears to protect against this type of hypertension is found mainly within the renal medulla.

The explants contained cells which appeared viable. The presence of mitotic figures involving renal epithelial cells 20 or more days after the explantation, and the arrangement of cells in clumps or clusters as well as in tubules, suggested expansion of the tissue in a proliferative sense. The main cell type contained a prominent clear cytoplasm in the regular hematoxylin and eosin preparation. The explants were smallest and least numerous in the group receiving a preparation of the outer medulla. This group, of those receiving medullary tissue, was the least protected against hypertension. Since whole kidney was most protective toward hypertension and cortex was not protective, it may be appropriate to speculate on differences between explants of whole kidney and outer medulla. Under the circumstances of the preparation used, a greater loss of cells in the blendor, through homogenization when outer medulla alone was used, was possible. Also, the viable-appearing cells in the whole kidney explant appeared to orient themselves about the absorbed and collapsed cortical tissue. Such orientation could conceivably have influenced the take and growth of the cells, a feature which was not available to the outer medullary explants. Thus, the differences in results between animals receiving whole kidney explants and those receiving medullary explants may have been due as well to technical as to other specific causes.

Protection against arteriolar thickening, as measured by the wall/lumen ratio of fixed tissues, was not observed for any group. The most encouraging results were noted in Group I (whole kidney explants) in which a suggestive protection against arteriolar thickening was encountered. Conversely, protection against arteriolar thickening or reversion of this change was observed in another study in which renal homotransplants were used 
following bilateral nephrectomy $(12,13)$. In the latter experiments uremia was relieved in part, while in the present experiments the level of urea mounted rapidly. The contrast between these results raises the issue of whether uremia per se may be a factor in the arteriolar thickening.

The protection against hemolysis in vivo observed following explantation of whole kidney (Group I), the partial protection against hemolysis observed following explantation of renal medulla (Groups II and III), and the lack of protection against hemolysis noted following explantation of renal cortex (Group IV), represent results in one parameter which correspond to the results in another parameter as revealed by the observations related to the cardiovascular system. The indication of protection against hemolysis characterizes further a function ( $s$ ) exerted by the explants which apparently is of nonexcretory type. As with the cardiovascular measurement, the function appears to be exerted mainly by medullary. renal tissue.

The nature of the function(s) exerted by the renal tissue, which appears to protect against renoprival hypertension and hemolysis, remains unresolved. As a consequence of the present experiments, attention may now be focused on the renal medulla as a potential major source of such a function (s).

\section{SUM MARY}

1. Renal tissue has been explanted to the peritoneum and lungs of the same dog. When whole kidney or renal medulla is explanted, certain cells appear to take hold and proliferate locally. The cells assume the appearance of tubules and irregular clusters and lack an organized excretory arrangement. The main cell type has a clear cytoplasm when observed in a regular hematoxylin and eosin preparation.

2. Protection against accelerated hypertension, as encountered following bilateral nephrectomy plus a sodium and protein intake, has been observed following explantation of whole kidney, whole renal medulla or outer renal medulla derived from one kidney followed by removal of the other kidney. The explanted animals received the same amount of sodium and protein as the nephrectomized group. Protection against accelerated hypertension was not afforded by explantation of renal cortex from one kidney followed by removal of the other kidney, or by explantation of the spleen or a portion of the liver followed by renal ablation.

3. Explanted whole kidney, whole renal medulla and outer renal medulla in the absence of both normal kidneys also affords protection against the hemolytic state as observed following bilateral nephrectomy. Explanted renal cortex does not protect against the hemolysis.

4. Suggestive protection against arteriolar thickening has been observed following whole kidney explantation but not following explantation of renal medulla.

5. The protective function(s) against the hypertensive state and the hemolysis appears to be of nonexcretory type and to be mainly within the renal medulla. The nature of this function(s) is unknown.

\section{ACKNOWLEDGMENT}

We wish to thank Dr. Jay Sanford for suggesting the antibiotic mixture used, and Dr. Sanford and Mr. Craig Wallace for testing the antibiotic mixture for toxicity by means of tissue cultures.

\section{REFERENCES}

1. Grollman, A., Muirhead, E. E., and Vanatta, J. Role of the kidney in pathogenesis of hypertension as determined by a study of the effects of bilateral nephrectomy and other experimental procedures on the blood pressure of the dog. Amer. J. Physiol. 1949, 157, 21.

2. Muirhead, E. E., Vanatta, J., and Grollman, A. Hypertensive cardiovascular disease: An experimental study of tissue changes in bilaterally nephrectomized dogs. Arch. Path. 1949, 48, 234.

3. Muirhead, E. E., Jones, F., Stirman, J. A., and Lesch, W. Hemolytic anemia of the dog following bilateral nephrectomy. Amer. J. Physiol. 1953, 173, 371.

4. Muirhead, E. E. Turner, L. B., and Grollman, A. Hypertensive cardiovascular disease: Vascular lesions of dogs maintained for extended periods following bilateral nephrectomy and ureteral ligation. Arch. Path. (Chicago) 1951, 51, 575.

5. Muirhead, E. E., Jones, F., Groves, M., and Brooks, B. Life span of erythrocyte following bilateral nephrectomy: Evidence for a rapidly acquired intracorpuscular defect (abstract). Amer. J. Med. 1957, 22, 971.

6. Orbison, J. L., Christian, C. L., and Peters, E. Studies on experimental hypertension and cardiovascular disease; method for rapid production of malignant 
hypertension in bilaterally nephrectomized dogs. Arch. Path. (Chicago) 1952, 54, 185.

7. Muirhead, E. E., Stirman, J. A., and Jones, F. Further observations on the potentiation of postnephrectomy hypertension of the dog by dietary protein. Circulat. Res. 1959, 7, 68.

8. Muirhead, E. E., Jones, F., and Stirman, J. A. Potentiation of renoprival hypertension by alanine, pyruvate and lactate. Amer. J. Physiol. 1957, 191, 537.

9. Wilson, W. A new staining method for demonstrating the granules of the juxtaglomerular complex. Anat. Rec. 1952, 112, 497.

10. Laboratory Manual of Special Staining, Armed Forces Institute of Pathology, Washington, D. C. 1953, 128.

11. Mallory, F. B. Pathological Technique. Philadelphia, W. B. Saunders Co., 1942, p. 170.

12. Muirhead, E. E., Stirman, J. A., Lesch, W., and Jones, F. The reduction of postnephrectomy hypertension by renal homotransplant. Surg. Gynec. Obstet. 1956, 103, 673.

13. Muirhead, E. E., and Stirman, J. A. Structural alterations of systemic vessels in response to systemic hypertension in Pulmonary Circulation, W. R. Adams and I. Veith, Eds. New York, Grune and Stratton, 1959.

14. Kernohan, J. W., Anderson, E. W., and Keith, N. M. The arterioles in cases of hypertension. Arch. intern. Med. 1929, 44, 395.

15. Sutherland, D. A., McCall, M. S., Groves, M., and Muirhead, E. E. The survival of human erythrocytes estimated by means of cells tagged with radioactive chromium: A study of the normal state. J. Lab. clin. Med. 1954, 43, 717.

16. Taylor, W. F., and Blair, W. M. Improved method for determination of blood urea nitrogen by direct nesslerization. J. Lab. clin. Med. 1932, 17, 1256.

17. Drabkin, D. L., and Austin, J. H. Spectrophotometric studies: Spectrophotometric constants for common hemoglobin derivatives in human, dog, and rabbit blood. J. biol. Chem. 1932, 98, 719.

18. Wintrobe, M. M. A simple and accurate hematocrit. J. Lab. clin. Med. 1929, 15, 287.

19. Chaplin, H., Jr. and Mollison, P. L. Correction for plasma trapped in the red cell column of the hematocrit. Blood 1952, 7, 1227.

20. Dameshek, W. A method for the simultaneous enumeration of blood platelets and reticulocytes. Arch. intern. Med. 1932, 50, 579.

21. Wintrobe, M. M. Clinical Hematology, 3rd ed. Philadelphia, Lea and Febiger, 1951, p. 239.

22. Muirhead, E. E., Groves, M., and Bryan, S. Positive direct Coombs test induced by phenylhydrazine. J. clin. Invest. 1954, 33, 1700.

23. Batson, H. C. An Introduction to Statistics in the Medical Sciences. Minneapolis, Burgess Publishing Co., 1956, pp. 54-60.
24. Croxton, F. E. Elementary Statistics with Applications in Medicine. New York, Prentice-Hall, 1953, pp. 235-240.

25. Goldblatt, H., Lynch, J., Hanzal, R. F., and Summerville, W. W. Studies on experimental hypertension: The production of persistent elevation of systolic blood pressure by means of renal ischemia. J. exp. Med. 1934, 59, 347.

26. Braun-Menendez, E., Fasciolo, J. C., Leloir, L. F., Muñoz, J. M., and Taquini, A. C. Renal Hypertension, L. Dexter, Trans. Springfield, Illinois, C. C Thomas, 1946.

27. Page, I. H. The renin-angiotonin pressor system in Symposium on Hypertension, E. T. Bell, B. J. Clawson, and G. E. Fahr, Eds. Minneapolis, Univ. of Minnesota Press, 1951, p. 48.

28. Floyer, M. A. Role of the kidney in experimental hypertension. Brit. med. Bull. 1957, 13, 29.

29. Grollman, A. Experimental studies on hypertension in Symposium on Hypertension, E. T. Bell, B. V. Clawson and G. E. Fahr, Eds. Minneapolis, Univ. of Minnesota Press, 1951, p. 22.

30. Braun-Menendez, E., and von Euler, U. S. Hypertension after bilateral nephrectomy in the rat. $\mathrm{Na}$ ture (Lond.) 1947, 160, 905.

31. Leonards, J. R., and Heisler, C. R. Artificial kidney : IV. Maintenance of life of bilaterally nephrectomized dogs and its relation to malignant hypertension. Amer. J. Physiol. 1951, 167, 553.

32. Houck, C. R. Effect of hydration and dehydration on hypertension in the chronic bilaterally nephrectomized dog. Amer. J. Physiol. 1954, 176, 183.

33. Kolff, W. J., and Page, I. H. Influence of protein and other factors on postnephrectomy hypertension in rats sustained with improved method of peritoneal lavage. Amer. J. Physiol. 1954, 178, 69.

34. Muirhead, E. E., Jones, F., Stirman, J. A., and Lesch, W. Experimental uremia: Excessive quantities of plasma protein and nitrogen removed in the outflow fluid during peritoneal irrigation of bilaterally nephrectomized dogs. Surg. Gynec. Obstet. 1953, 97, 189.

35. Braun-Menendez, E. Experimental hypertension in Symposium on Hypertension, E. T. Bell, B. J. Clawson and G. E. Fahr, Eds. Minneapolis, Minnesota Univ. Press, 1951, p. 161.

36. Muirhead, E. E. Experimental hypertension following bilateral nephrectomy; influence of protein and sodium on its pathogenesis. Sth. med. J. (Bgham, Ala.) 1954, 47, 110.

37. Muirhead, E. E., Jones, F., and Graham, P. Hypertension following bilateral nephrectomy of dog: The influence of dietary protein on its pathogenesis with emphasis on its development in the absence of "extracellular fluid" expansion. Circulat. Res. 1953, 1, 439. 
38. Grollman, A., Turner, L. B., Levitch, M., and Hill, D. Hemodynamics of bilaterally nephrectomized dog subjected to intermittent peritoneal lavage. Amer. J. Physiol. 1951, 165, 167.

39. Turner, L. B., and Grollman, A. Role of adrenal in pathogenesis of experimental renal hypertension as determined by study of bilaterally adrenalectomized dog. Amer. J. Physiol. 1951, 167, 462.

40. Muirhead, E. E., Jones, F., and Graham, P. Hypertension in bilaterally nephrectomized dogs in absence of exogenous sodium excess; maintenance of fluid balance during peritoneal irrigation. A.M.A. Arch. Path. 1953, 56, 286.

41. Kolff, W. J., Page, I. H., and Corcoran, A. C. Pathogenesis of renoprival cardiovascular disease in dogs. Amer. J. Physiol. 1954, 178, 237.

42. Kolff, W. J., and Page, I. H. Blood pressure reducing function of the kidney: Reduction of reno- prival hypertension by kidney perfusion. Amer. J. Physiol. 1954, 178, 75.

43. Merrill, J. P., Murray, J. E., Harrison, J. H., and Guild, W. R. Successful homotransplantation of human kidney between identical twins. J. Amer. med. Ass. 1956, 160, 277.

44. Blaquier, P., Gomez, A., and Hoobler, S. W. Role of the intact kidney in experimental hypertension. Fed. Proc. 1958, 17, 16.

45. Muirhead, E. E., Stirman, J. A., and Jones, F. Dietary protein and hypertension of dog: Protection by uretero-caval anastomosis and ureteral ligation. Fed. Proc. 1958, 17, 115.

46. Muirhead, E. E., and Stirman, J. A. Dietary protein and hypertension of dog: Protection by uretero-caval anastomosis with a study of kidneys so treated (abstract). Amer. J. Path. 1958, 34, 561.

\section{ANNOUNCEMENT}

A Grant Award for travel funds to the First International Congress of Nephrology in Geneva, Switzerland, September 1, 2, 3, 1960, has been awarded by the U.S.P.H.S. to the American Society for Clinical Investigation.

Members and nonmembers are eligible to apply for travel funds to the Congress. Funds are available to send 20 individuals to the meetings.

Applications for funds should include in quadruplicate:

a) Letter of application stating interest in the field and in the Congress.

b) Curriculum vitae.

The deadline for receipt of $a$ ) and $b$ ) is March 1, 1960. Awards will be made around March 15, 1960.

Applications should be sent to Saul J. Farber, Secretary, American Society for Clinical Investigation, New York University College of Medicine, 550 First Avenue, New York 16, New York. 